\title{
Not Waving but Striving: Research Collaboration in the Context of Stratification, Segmentation, and the Quest for Prestige
}

\author{
Blanca Minerva Torres-Olave \\ Loyola University Chicago, btorresolave@luc.edu
}

Ashley M. Brown

Loyola University Chicago

Lillianna Franco Carrera

Loyola University Chicago

Carlos Ballinas

Loyola University Chicago

Follow this and additional works at: https://ecommons.luc.edu/education_facpubs

Part of the Education Commons

\section{Author Manuscript}

This is a pre-publication author manuscript of the final, published article.

\section{Recommended Citation}

Torres-Olave, Blanca Minerva; Brown, Ashley M.; Franco Carrera, Lillianna; and Ballinas, Carlos. Not Waving but Striving: Research Collaboration in the Context of Stratification, Segmentation, and the Quest for Prestige. Journal of Higher Education, , : , 2019. Retrieved from Loyola eCommons, Education: School of Education Faculty Publications and Other Works, http://dx.doi.org/10.1080/00221546.2019.1631074

This Article is brought to you for free and open access by the Faculty Publications and Other Works by Department at Loyola eCommons. It has been accepted for inclusion in Education: School of Education Faculty Publications and Other Works by an authorized administrator of Loyola eCommons. For more information, please contact ecommons@luc.edu.

\section{c) (i) $\odot$}

This work is licensed under a Creative Commons Attribution-Noncommercial-No Derivative Works 3.0 License. (C) Taylor and Francis, 2019. 
Running head: RESEARCH COLLABORATION IN THE CONTEXT OF STRATIFICATION

This is an Accepted Manuscript of an article published by Taylor \& Francis in The Journal of Higher Education on June 28, 2019, available online: https://www.tandfonline.com/doi/full/10.1080/00221546.2019.1631074.

Not Waving but Striving: Research Collaboration in the Context of Stratification, Segmentation, and the Quest for Prestige 
Collaboration in research and publication is a growing phenomenon in academia. The inherent complexity of the challenges facing our world (e.g. disease, climate change, economic inequality, mass migration and displacement, inter-group conflict, to name a few) calls for the integration of cross-disciplinary skills and knowledge to better understand and ameliorate these problems (Stokols et al., 2008). As such, government agencies and other organizations increasingly incentivize research collaboration at institutional, national, and international levels as part of their funding conditions (Lee \& Bozeman, 2005; Van Rijnsoever \& Hessels, 2011). In this context, researchers at higher education institutions (HEIs) are increasingly expected to work as partners not only with other academics, but also with industry, government, and communitybased organizations (Kollasch, Rios-Aguilar, Torres-Olave, \& Rhoades, 2016).

A tension inherent in collaborative endeavors is that they take place within a policy and organizational environment characterized by intense competition and resource stress (Metcalfe, 2010, p. 506). As public funding declines and research funding is disproportionally allocated to a few fields of study (Corzo, 2015; Hoyla, Bartneck, \& Tiihonen, 2016), HEIs turn to strategies to minimize uncertainty in the resource environment and gain a standing in the competition for scarce resources (Pucciarelli \& Kaplan, 2016; Toma, 2012). Research collaborations and partnerships emerge as an attractive and, to some observers, perhaps inevitable strategy in the competition for limited resources (Goel et al., 2017).

However, not all HEIs and not all actors within those institutions are equally positioned to succeed in the competition for scarce resources. First, institutional differentiation based on factors like resources, prestige, and geographical context means that some institutions are better positioned to engage in high-stakes collaborations and partnerships, such as those involving technology transfer (O’Shea, Allen, Chevalier, \& Roche, 2005; Sine, Shane, \& Di Gregorio, 
2003; Wright, Clarysse, Lockett, \& Knockaert, 2008). This type of institutional stratification is an important mediator in collaborative activities, with faculty at teaching-oriented institutions being less likely to have extensive collaboration networks than their counterparts at researchintensive institutions (Kollasch et al., 2016). Moreover, as a notoriously hierarchical environment, collaboration can be mediated by the same factors that contribute to academic labor segmentation, such as discipline (Gardner, 2013; Klein, 2005), professional rank (Bozeman \& Corley, 2011; Bozeman, Fay and Slade, 2013), and gender (Bozeman \& Corley, 2011).

In this article we examine the ways in which institutional stratification and academic labor segmentation can play a significant role in shaping faculty collaborative activities. Our study was concerned with two main questions: What is the impact of an institution's resource environment and relative position in the prestige hierarchy on faculty collaborative activities? And, what is the impact of labor segmentation on faculty collaborative activities? We draw on interviews from faculty at two institutions in the United States to explore the ways in which differential access to material and symbolic resources (such as prestige) contribute to creating significantly distinct experiences of collaboration.

The remainder of the article is organized as follows. We first examine collaboration as a form of resource exchange involving both material and emblematic resources like prestige. We also explore the isomorphic pressures that HEIs face to emulate the standards, values, and strategies of high-status institutions in the quest to remain competitive. By considering the ways in which a university's relative position in the institutional status hierarchy has a significant impact on the types of resource it can access and mobilize, we identify how existing patterns of inter-institutional stratification and intra-institutional segmentation are reinforced. We then 
discuss the data collection and analysis methods used in the study followed by our presentation of the findings and concluding remarks.

\section{Background: Collaboration as Resource Exchange}

The importance of research collaborations is evidenced by the significant body of literature devoted to different aspects of the former, including their definition, operationalization, and measurement (Bozeman et al., 2013; Kezar, 2005; Savanur \& Srikanth, 2010; Sonnenwald, 2007), factors that contribute to or hinder collaboration (Bruneel, D'este, \& Salter, 2010; Perkmann \& Salter, 2012; Thune \& Gulbrandsen, 2014), and the development of models and typologies of collaborative activity (Bozeman \& Corley, 2004; Kezar, 2005; Sonnenwald, 2007). One of the main difficulties in the study of research collaborations is the ambiguity of the term (Bozeman et al., 2013; Eddy 2010; Katz \& Martin, 1997; Kezar, 2005; Laudel, 2002;

Sonnenwald, 2007), as "collaboration" can refer to a broad spectrum of formal to informal relationships varying significantly in size and scope. Eddy (2010) calls attention to a pragmatic distinction between "partnerships" as a wide range of organizational-level joint ventures (e.g. strategic alliances, joint ventures, consortia, and so on) "between or among institutions, through departmental alliances across institutions, with university programs that pair with community agencies." In contrast, collaboration more commonly denotes a type of relationship involving faculty pairings across institutions - which in some cases may in turn spur the development of larger, more formalized organizational partnerships (Eddy, 2010, p. vii).

Despite the various possible interpretations of "collaboration," a common thread in most definitions is the act of working with others, as implied in its etymology (Keohane, 1985). Because the labor involved in establishing and sustaining collaboration activities typically requires a substantial investment of time, effort, and infrastructure, an important assumption 
underlying any collaboration initiative is that its benefits outweigh the costs (Austin \& Baldwin, 1991; Katz \& Martin, 1997). In this sense, collaboration is an exchange of resources that takes place when two or more parties believe that joint working can help preserve or enhance key organizational resources (Connolly \& James, 2006). At the institutional level, this can include attracting third-party revenue streams in the form of grants or other forms of sponsorship. For individual faculty, collaboration may likewise increase opportunities to access valued resources, including funding, instrumentation, data, expertise, as well as other scarce natural and social resources (Sonnenwald, 2007). For private companies, collaborating with a university may involve the co-opting of prestige and the potential commodification of scholarship (Corzo, 2015; D'Este \& Iammarino, 2010), the creation of innovative products and materials that can enhance the value of a company (Bruneel et al., 2010), and the development of programs for training a specialized workforce (Morgan \& Mulligan, 2014).

Crucially, the resource exchange involved in research collaboration includes not only material resources like money, instrumentation, or infrastructure. Access to emblematic resources like prestige (Metcalfe, 2010) and social resources in the form of networks are just as important in the exchange involved in collaborative activities. In the academic marketplace, prestige acts as a rival good in that one institution's consumption of prestige precludes another from accessing that particular level (Brewer, Gates, \& Goldman, 2002; Cantwell \& Taylor, 2013; Slaughter \& Cantwell, 2012). Understanding institutional decision-making in terms of such individual gains and losses underscores the competitive dynamic within higher education, especially considering of the impact that institutional prestige and wealth have on a university's ability to access new valuable resources. 


\section{"Striving" for Prestige in the Context of Institutional Stratification}

An important corollary to collaboration as resource exchange is that the market-like systems of university resource allocation are generally designed to reward the "fittest" institutions - those that more closely fit the "excellence" criteria of the so-called "world-class" institutions (Cantwell \& Taylor, 2013). While the "world-class" concept is widely used by institutional leaders and policymakers, its meaning is ambiguous, and "higher education institutions quite often neglect to set out in what respect they consider themselves world-class, excellent or leading, let alone that they deliver any proof of their position" (Huisman, 2008, p. 2). The label, however, is frequently synonymous with what Mohrman, Ma, and Baker (2008) refer to as the Emerging Global Model (EGM) of the university. Institutions fitting this model are at the forefront of interdisciplinary, team-oriented research aimed at solving real-world problems. EGM institutions tend to develop complex organizational structures to help support research, which in turn requires a considerable and diversified funding base from both public and private sources. Finally, being global in mission and scope, institutions fitting the EGM engage in worldwide competition for students, faculty, staff, and resources (Mohrman et al., 2008, p. 6).

High-status EGM institutions generally possess extensive resources in the form of diversified funding, infrastructure, and prestige, which in turn give them an advantage in competitions to secure additional wealth. Likewise, increases in virtual resources have a significant impact in sustaining or increasing material resource flows, creating a kind of virtuous circle of accumulative advantage (Bastedo \& Bowman 2011, p. 8). For example, there is evidence that institutions with the most accumulated wealth-as measured by input resources such as R\&D income - tend to attain higher positions in influential markers of status, such as global ranking systems (Cantwell \& Taylor, 2013). Moving up in the national and international 
rankings has positive effects in terms of the quantity and quality of students that apply to the institution (Ehrenberg, 2003). It may also contribute to steering more per student state funds towards public institutions (Zhe Jin \& Whalley, 2007), as well as greater private donations by donors who wish to invest in the most prominent research institutions (Cheslock \& Gianneschi, 2008). Finally, better-resourced, research-intensive institutions are in a position to recruit wellestablished faculty and researchers who can build strong research programs and attract revenue for the university through grants and contracts. This competitive advantage also provides a degree of stability from which university actors may continue to upgrade their assets and capacities (Toma, 2012).

However, not all institutions can afford to compete in the quest for prestige on an equal level. The high cost of conducting research means that universities with fewer resources "fall farther behind their advantaged peers by losing competitions for additional resources," thus reinforcing existing patterns of inter-institutional stratification (Cantwell \& Taylor, 2013, p. 203). As they seek legitimacy in a competitive environment, HEIs will try to emulate the standards, values, and strategies of high-status institutions. Such "striving" institutions (O’Meara, 2007) will make changes to operational areas associated with prestige indicators, such as modifying student admission criteria to increase selectivity, reallocating resources towards knowledge production activities and facilities, and enhancing the institution's knowledge production profile by recruiting and rewarding faculty with a strong research orientation (O’Meara, 2007). Conformity to the norms of top-competitors along these areas is expected to result in increased resource flows, both material and emblematic. While the pressure to adhere to these standards is intense across all HEI sectors, it may be especially intense for institutions in the lower echelons of the prestige hierarchy. Thus, despite strong environmental pressure to 
emulate their high-status counterparts, lower-status institutions find themselves at a severe disadvantage.

\section{Intra-organizational segmentation by field of study and employment status}

The increasing use of competition as a finance allocation device in higher education is associated not only with inter-institutional stratification, but also with intra-organizational stratification, often referred to as segmentation (Slaughter \& Cantwell, 2012). According to Cantwell and Taylor (2013), one type of segmentation refers to material asymmetries that separate some units from others within universities, particularly in terms of their relative prestige and ability to attract external funds. These characteristics have been observed to result in the advantaging of some fields (and programs) relative to others. For example, the ability of programs closer to market (such as those in the hard sciences) to attract grants and other external resources can facilitate a "halo effect" where "the prestige of individual departments generates prestige for the institution as a whole, [and] people begin to associate high-quality research in a specialized field with quality research more generally" at the university (Brewer, Gates, \& Goldman, 2002, p. 69).

A second type of intra-organizational segmentation refers to the casualization of academic labor, that is, the growing restructuring of tenured and tenure-track (T/TT) faculty jobs into non-tenure-track (NTT) positions. The rise of contingent faculty is linked to the broader restructuring of the labor force in the new economy, declines in government spending on education, and the growing corporatization of colleges and universities (Kezar \& Sam, 2010; Slaughter \& Rhoades, 2004). From an institutional viewpoint, one of the main attractions of using contingent faculty is the flexibility that institutions can exercise in reallocating resources. However, from the viewpoint of the individuals in these positions, the labor conditions may be 
less than ideal. Some issues of concern regarding the increasing use of contingent faculty include employment status, workload and compensation, union membership, academic freedom, and the quality and consistency of workplace conditions for faculty. Sustained contingent, nonranked status often results in a "second-class" stigma with very real consequences for those in part-time (and full-time non-tenure-track) positions, including professional isolation, exclusion from curricular discussions, and a general sense of "invisibility" in departmental and university life (Kezar, 2012; Kezar \& Sam, 2010). The extent to which this cumulative disadvantage impacts collaborative activities has not been explored in detail.

\section{Data and Methods}

The present study was part of a large-scale international collaborative project aimed at investigating how higher education institutions are connected to and within contemporary societies. The project was initially carried out by local teams in four European countries (Finland, Germany, Portugal, and the United Kingdom) and in two states in the United States. The sequential mixed-methods study involved a series of iterative data collection and analysis stages, including institutional case studies at selected institutions in each country, and an international comparative survey focused on academics' social networks. The design and methods within and across research stages are discussed in detail in prior publications (TorresOlave, Horta, Kollasch, Lee, \& Rhoades, 2016; see also Hoffman \& Horta, 2016).

Data for this article come from Phase 2 of the institutional case studies stage. Each case study had two phases consisting of a series of qualitative, semi-structured interviews with senior institutional leaders and managers (Phase 1, restricted to European teams) and with key actors of knowledge production, transfer, and transmission networks, namely faculty, managerial professionals, and non-faculty professionals (Phase 2, all teams). Likewise, Phase 2 was 
subdivided into two distinct data collection instruments: Instrument 2 a consisted of a common sociometric survey implemented all seven countries (see Hoffman and Välimaa, 2016 for full instrument, and Kollasch et al. 2016 for comparative findings). In turn, Instrument $2 \mathrm{~b}$ consisted of a common interview protocol constructed around six main, interrelated themes: 1) The participant's relationship to the institution; 2) Changing notions of clients, audiences and users; 3) Changing notions of networks, partners and collaborators; 4) Interplay of competition and collaboration; 5) The teaching function; and 6) Boundaries between teaching, research and knowledge transfer functions. Because of the significant differences in national academic cultures, each team further adapted this instrument to suit the local context. In the remainder of this section, we focus exclusively on the data collection and analysis procedures for Phase $2 \mathrm{~b}$ in the United States.

\section{Case Studies: EGM and non-EGM institutions}

Conducting an interpretive case study involves collecting data within finite parameters with the intention of describing and analyzing the unit of study comprehensively to develop general theoretical statements about the group or phenomenon under study (Yin, 2014). The research sites for this study were two public universities (identified by pseudonyms): 1) Midwest University (MidU); and 2) Regional Midwest University (RMU). Both are relatively large universities located in the same state in the Midwest U.S. with enrollments ranging between 41,000 and 28,000 students, respectively, at the time of the study. However, the institutions differed significantly in terms of resources and prestige. MidU closely fits the criteria stipulated by the Emerging Global Model (EGM) in that it is a research-intensive, highly prestigious institution with a global reach. In contrast, RMU is a considerably less prestigious, regional doctoral-granting university. Interviews also took place at a third high-prestige, high-resource 
institution located in the Pacific region to have a comparison point for EGM institutions across state policy contexts. In this article, we focus only on the two institutions located in the Midwest to eliminate variability across state policy contexts.

There are significant differences in the financial situation of the two institutions which, as we show in the findings, can play a significant role in faculty's access to symbolic and material resources needed for collaboration. For example, Figure 1 shows the total operating revenues for both institutions in fiscal years 2007 and 2017. In 2017, RMU's total operating revenue was above $\$ 330$ million dollars, a significant increase from about $\$ 245$ million in 2007 . In turn, MidU's total operating revenues were \$3.7 billion in 2007 and \$6.8 billion dollars in 2017 (National Center for Education Statistics [NCES], 2018).

[Insert Figure 1 about here]

A look at the institutions' sources of core revenues per FTE enrolment is also revealing, as seen in Table 1. In 2017, the primary source of core revenue for both institutions came from tuition and fees, though this proportion was much higher in the case of RMU. As a researchintensive institution, MidU derived a high proportion (22\%) of its core revenue from government grants and contracts, or $\$ 21,107$ per FTE. This stands in stark contrast to the figures for RMU, where government grants and contracts represented about $8 \%$ of core revenues, or $\$ 1,659$ per FTE (NCES, 2018). Notable differences are also evident in the proportion and total amount of core revenue that comes from private gifts and grants as well as returns on investment at each institution.

[Insert Table 1 about here]

Unsurprisingly, there are significant differences in operating grants and contracts at the federal, state, and local levels between the two institutions. For example, RMU has clearly seen 
an increase in federal grants and contracts from \$4,261,114 in 2007 to \$7,513,164 in 2017. However, these figures represent a mere $.6 \%$ to $.8 \%$ of the total amount of federal grants and contracts obtained by MidU in the same period.

[Insert Figure 2 about here]

A final measure of an institution's fiscal capacity is its endowment. Thanks to a vigorous fundraising effort in recent years, RMU nearly doubled its endowment assets from $\$ 82$ million dollars in 2007 to about $\$ 156$ million in 2017. In the same period, MidU's endowment assets grew from close to $\$ 7$ billion to just over $\$ 10$ billion dollars (Figure 3). The size of MidU's endowment gives it a significant advantage in that $31 \%$ of the institution's total revenue in 2017 came from return on investments alone, as shown in Table 1. Moreover, in 2017 alone, MidU totaled $\$ 136$ million in new additions to its permanent endowment—almost the amount of RMU's entire endowment assets that same year (NCES, 2018).

[Insert Figure 3 about here]

\section{Data Collection Procedures}

We conducted a total of nineteen in-depth, semi-structured interviews. Semi-structured interviews are a useful strategy for investigating a topic, event or phenomenon from the perspective of those who have experienced it and makes it possible for participants to share detailed historical and biographical information that may be lost in other approaches, such as onsite observations or surveys (Galletta, 2013). Because of the project's focus on changing structures of academic work and collaboration networks spanning industry, government, and other non-university partners, we recruited tenured/tenure-track and non-tenure track faculty and researchers in the life sciences, physical sciences, and engineering fields at both institutions. Participants in these fields were recruited through typical case purposeful sampling, the purpose 
of which is to describe and illustrate what is typical to those unfamiliar with the setting, rather than to make generalized statements about the experiences of all participants (Palinkas, Horwitz, Green, et al., 2015). As mentioned above, this qualitative interview component was embedded in a larger sociometric survey at the same sites for the purpose of complementarity.

All interviews were digitally recorded, transcribed, and analyzed thematically. In the data analysis stage, we followed coding procedures for descriptive/interpretive analysis. This involved developing initial codes based on three main sources: the participants' responses to interview questions, the research questions and sub-questions, and the concepts and categories suggested by the theoretical framework and related literature (Tesch, 1990). Codes with similar content were clustered and systematically analyzed for patterns or relationships, from which we developed broader conceptual categories.

\section{Findings}

We begin the presentation of the findings by briefly describing the collaboration patterns at MidU, an institution representative of the EGM in terms of its global reputation as a leader in interdisciplinary research and complex organizational structure designed to support knowledge production and transfer activities. These characteristics placed MidU faculty in an excellent position to engage in intensive collaborative activities with multiple partners around the world, as well as to generate additional revenues to support the research enterprise. However, our data showed that shifting labor arrangements at MidU have influenced the ways in which research collaborations are approached and formed, particularly by faculty and researchers in non-tenuretrack (NTT) positions. These tensions highlight the role that labor segmentation and isomorphic pressures in the pursuit of prestige can have in the labor and collaboration relations of NTT faculty. Next, examine the ways in which collaboration dynamics played out among faculty at 
RMU as it strived to align itself closer to the EGM while facing considerable disadvantage relative to more prestigious institutions like MidU. The findings illustrate the impact that the stratification and segmentation dynamics can have on how faculty engage in a range of collaborative activities, from peer-to-peer research collaboration to partnerships with industry.

\section{Collaboration and Labor Segmentation at an EGM Institution: The Case of MidU}

Consistently ranked amongst the top 50 US institutions in global rankings, MidU emerged as a prototypical EGM institution. With research expenditures nearing one billion dollars annually, the institution requires an intricate organizational structure to support the research enterprise. Aside from the research that occurs within traditional academic units (e.g. schools, colleges, and academic departments), MidU is home to over a hundred centers and institutes focused on long-term interdisciplinary problems. Likewise, the institution has developed a complex, differentiated staffing system to support its instructional and research activities. In addition to the well-established instructional tenure-track with responsibilities for teaching, service, and research, MidU also maintains the following non-tenure-track faculty: 1) a clinical instructor track (with three seniority ranks) varying widely in terms of their teaching, service, and research expectations; 2) a research scientist track (with four seniority ranks) entailing a full-time career in research; 3) a research professor track (with three seniority ranks) with expectations of teaching, mentoring, and research. The institution also employs a cadre of predominantly teaching-oriented adjuncts, lecturers, and clinical lecturers. For any of these positions, joint appointments in two or more departments are available for faculty who engage in substantial academic or clinical collaboration beyond routine collegial interactions.

This level of differentiation across institutional units and faculty work is congruent with the EGM expectation that research-intensive institutions will develop great internal complexity 
to support research. This dynamic was corroborated in the interviews. "[O]f course, the research enterprise itself has also morphed from the single investigator model to these much larger interdisciplinary center models where there's also more involvement of industry, more involvement of maybe NGOs and the likes, changing landscape also in the research arena" [Dr. K, Professor, Energy Institute]. At the same time, our interviews suggested that these changing structures and roles also gave rise to elements of intra-institutional segmentation and competition not considered in discussions of EGM characteristics, but which have a significant impact in shaping faculty work and approaches to collaboration. The experience of faculty at the MidU Transportation Institute is a case in point and will be analyzed in the next section.

\section{Competition and labor segmentation at the MidU Transportation Institute}

The MidU Transportation Institute is a multimillion applied research center. In contrast to more traditional academic departments at MidU, funding for the Institute comes entirely from non-university sources such as research grants and contracts from government, industry, and nonprofit sectors. Although some T/TT faculty have appointments at the Institute, the primary affiliation for these faculty was with one of the more "traditional" academic departments, such as psychiatry and materials science engineering. The Institute predominantly employed faculty from the research scientist and research professor tracks who have full-time appointments but different work expectations than tenure-track faculty. Dr. G, a Research Scientist, explained that faculty in the research track "can be part of an academic department but you don't teach classes, you're not a professor; you don’t necessarily have students."

Along with different work expectations relative to the T/TT faculty came a significantly different funding structure and perceived status for the non-tenure track faculty. Although research scientists at MidU receive a base salary and benefits, the former is often significantly 
lower than that of their T/TT counterparts. Faculty on the research scientist/professor tracks are expected to supplement their base salary through external funds. "[Those] in the research track are on soft money, which means we bring in our salaries through grants and contracts. We don't get any of the general funds that come in, you know, like the normal faculty get." [Dr. G, Research Scientist]

With a considerable portion of their salaries on the line, faculty on the research track were adept at locating opportunities for funding and at catering to the research interests of potential sponsors. When asked to what extent research scientists at the Institute set their own research agendas, Dr. H., an Assistant Research Scientist, laughed and explained, [You] can do research if you can get funding to do research on it! We work on proposals probably monthly, we have industry and government contacts.... [O]ther times we'll have industry people come to us. Sometimes we have our own ideas that we will send out unsolicited to possible sponsors and they go with that, so. So yeah, it's different ways of getting those funds for what we're doing.

The funding structure of the Transportation Institute set it apart from other academic departments and research centers at MidU in ways that significantly impact how faculty approach their work - especially in terms of establishing partnerships and collaborations. For example, the need to aggressively pursue external funding rendered an extremely competitive work environment for research faculty at the Transportation Institute, where rivals ranged from organizations in the private sector, industry associations, nonprofit organizations, to other units and colleagues within MidU. Professor I, an Assistant Research Scientist, stated, "I do battle against some consulting organizations, private. There are some nonprofit organizations that act 
as consulting companies. It's hard to believe, but they exist." Additionally, "some of the industry associations are competitors, because they end up doing some of the research work that in the past may have been done by myself and my group." Significantly, interviewees also identified other units within MidU working on related projects among their main competitors. "The trauma department here within the university are, on some levels, very tough competitors... We're always finding ourselves going for the same pots of money." [Dr. J, Research Professor] This experience contrasted with that of faculty at other MidU research centers and academic units that did not rely exclusively on soft money. For example, MidU is home to the Energy Institute, whose main focus is promoting interdisciplinary energy-related research across campus, including the social sciences, engineering, chemistry, and physics. The Energy Institute differed from the Transportation Institute in terms of its funding structure, as suggested by Dr. K:

The [Energy] Institute has its own line-item funding from the general fund of the university for the personnel and, in addition to this, there is discretionary money provided by the university that comes from the various colleges. Then there are also several research contracts that are administered through this Institute; some of them, for example, from the [U.S.] Department of Energy and the likes [Dr. K, Director, Energy Institute].

In addition to having its own line-item funding from both the general fund and departmental funds of the university, the Energy Institute was active in helping faculty across the university apply for grants and other external funding. Because faculty salaries are not directly dependent on soft money, the staff can focus less on bringing in grants and contracts and, instead, place attention on the impact of research on graduate students and industry partnerships: 
So that is also a new development that we are engaging in much more closely with industry.... We are not just on the receiving end of some industrial donation or on the receiving end of maybe a contract to send some money our way to do a project; we are actually partnering with them where we work side-by-side [Dr K, Director, Energy Institute].

As a result of this stability, Dr K saw the Energy Institute as having competitive advantage relative to potential competitors. "I think we are fairly unique and I wouldn't see a lot of competition for us in the sense that our institute is extremely broad in its reach." Significantly, while the Transportation Institute research faculty spoke of other units at MidU as potential competitors, Dr. K framed them as allies, even in areas where there was a clear overlap in their interests. "[The] major technology strength of our Institute is in the automotive sector," he observed. "[MidU] is very fortunate to have enormous strength in many disciplines sort of across the board."

A surprising development that emerged in the interviews was that, while the Transportation Institute researchers must strategically obtain soft money to make up part of their salary, they also faced pressures from within the university to operate more like the Energy Institute or a traditional academic unit. In recent years there had been a push for researchexclusive units to align with certain expectations of academic departments, including forming close connections between research and teaching operations.

I think they wanted us to be less of a contract shop and move towards an academic and scholarly approach to the work that we do ... They wanted us to be more like a regular university unit. But then, what that meant was unclear because they weren't willing to 
accord money support to do teaching, and they weren't particularly supporting of efforts to develop some kind of degree program. [Dr. J, Research Professor].

The expectation to make the Institute operate more like an academic unit placed an additional burden on the research scientists not commensurate with compensation nor promotion standards. Dr. H, an Assistant Research Scientist, explained that MidU was trying to align the promotion standards for research scientists at the Transportation Institute with those in the College of Engineering, meaning that research-track faculty would be expected to take on some teaching and service duties, yet without an expectation of tenure or the kind of funding structure that supported these activities at the College of Engineering. Asked why MidU would want research scientists to take on more teaching duties, Dr. $\mathrm{H}$ posited that the tenure track is perceived as more prestigious and with more rigorous hiring standards than those of research scientists. "I was involved in a faculty search [for the Institute] and there was somebody from the College of Engineering on our search committee and they were like 'oh yeah, [that candidate] is fine, but he would never be hired in the College of Engineering." Thus, the drive to increase the teaching and service expectations of research-track faculty was at least partly an attempt to preserve the status of the institution as devoted to ideals of knowledge pursuit and education, rather than a pedestrian "contract shop." Significantly, these additional expectations of the research faculty did not consider just how much time and energy research faculty at the Transportation Institute had to devote to establishing connections to potential partners and sponsors. 


\section{"Striving" at a Regional, Teaching-Oriented Institution: The Case of RMU}

RMU is a public, 4-year institution recently classified as a doctoral/research-intensive university by the Carnegie Foundation. Although RMU stresses its identity as a teachingoriented institution, in the past two decades upper administration began taking steps to enhance its research profile. Among these efforts were the allocation of over $\$ 3$ million to help establish 11 new research centers and the creation of a Research Corporation (RC) with facilities that included a business incubator space and a technology park to facilitate partnerships with the private sector. During this period, RMU also inaugurated an Office of Sponsored Research (OSR) overseen by a Vice President for Research and Dean of Graduate Studies. The OSR was charged with supporting faculty secure and manage external grants and to facilitate technology transfer activities.

The push to increase the research profile of the institution was also evident at the academic unit level. Interviewees across different departments spoke about concerted efforts to recruit a greater number of faculty with a research orientation. Dr. B, Chair of the Physics Department, recalled the change in his program since he was first hired in the early 1990s. His own training as a postdoc was unusual for new RMU hires, given that "the Physics Department was not terribly active research wise. I think there were 12 tenure track lines, and they might have published a total of 3 or 4 papers a year." In the years since, the department has "tried to find people who are happy and interested in balancing teaching and research [and] to hire always people who've had post doc experience. That has helped us to become a much more research active department."

The institutional pressure to conduct more research at an institution historically committed to teaching and service is consistent with the pattern of "striving" institutions 
attempting "a variety of approaches to reposition themselves toward greater prestige - and they assume, increased resources" (Toma, 2012, p. 123). At RMU, the shift was intricately linked to a years-long shift in policy during which state allocations for institutions like RMU declined considerably, and which led to significant tuition increases to make up for the loss in public revenue. RMU's "research turn" - which greatly emphasized technology transfer-was part of the institutional strategy to attract larger shares of external revenue through research grants and closer connections to industry.

However, our interviews with RMU faculty illustrate the considerable disadvantage faced by non-elite institutions seeking to emulate the type of entrepreneurial activities privileged by the EGM model. Prestige emerged as a real and significant barrier to establishing partnerships with industry. For example, RMU is located close to the global headquarters of a world-renowned chemical company. The company had historical ties with the RMU Chemistry Department, including participating in research collaborations, donating funds for infrastructure, and sponsoring employees to pursue degrees at RMU. This relationship had grown tenuous in recent decades, however. According to the Chair of the Physics Department, for years "the dream of some of the Chemistry faculty has been... to build a $\mathrm{PhD}$ program here that would allow them to work more closely with scientists at [the company]. They saw it as a good opportunity for RMU" [Dr. B, Chair, Physics]. The Chemistry faculty had lobbied the RMU administration to establish a PhD program, with little success. It was not until a joint effort between the Physics and Chemistry faculty that led to the creation of an interdisciplinary doctorate in advanced materials science.

Historically, the Physics and Chemistry departments had been rivals in recruiting undergraduate seniors and graduate students. By becoming collaborators "based on common 
interests and communal strength" [Dr. B, Chair, Physics] they were able to push forth a mutually beneficial initiative. However, trying to leverage the new program into the kind of strategic joint ventures premised by RMU's aspirations had mixed results. Dr. A, a Professor in the Physics Department, explained that although involvement with the chemical company existed, it remained piecemeal. "As far as getting financial support, it's kind of on a project by project basis. It's usually some kind of contractual work." Getting student support, as in the form of paid internships, was more difficult. "My understanding is, is that [the Company has] a list of favored universities where they support internship programs. And these are the Stanfords and MITs and places like that. A colleague of mine tried mightily this past year to get our PhD student some kind of internship and in the end it didn't work out." Dr. D, an Associate Professor in Chemistry who had been involved in the development of the $\mathrm{PhD}$ program, put it more bluntly: "I mean, [the Company] at this point has pretty much cut all other involvement, because they only work pretty much with the biggest universities."

Likewise, our interviews suggest that the transition to becoming a more research-oriented institution brought about significant challenges in terms of the considerable financial investment, expertise, and infrastructure necessitated by technology transfer. Dr. D's experience illustrates this point well. At the time of the interview Dr. D had a project with commercialization potential and was actively trying to secure patents for her work. As mentioned earlier, an office of technology transfer had been recently inaugurated at the institution, and Dr. D turned to them to determine the next steps in the process. However, she found that RMU's infrastructure to support patent development was very limited. Dr. D described herself as the "guinea pig" through which RMU's novice office of technology transfer would begin to test the waters of 
patent development. Additionally, the high cost of patenting was a considerable barrier given RMU's limited financial capacity.

Nine or eight years ago, about seventy-five of the budget for RMU came from the state... Now it's seventeen [emphasis hers]. So obviously our budget has shrunk continuously, and the cost of our classes has gone up too consistently. So we have severe funding issues if we talk about patents. For example we are trying to turn one of my provisional patents into fully international patent. In the ideal case that patent alone would be $\$ 150,000$. [Dr. D, Assistant Professor, Chemistry]

The institution did not have the resources to cover the expenses associated with the patent. Dr. D was aware of a drive on the part of the RMU leadership to secure greater investment in research that would allow projects like hers to get off the ground. However, she also pointed out that convincing the legislature and the private sector to invest in regional institutions like RMU was difficult. “[T]here's not much expectations [for regional institutions] because we're not known for research yet." Instead, these institutions found themselves competing for funds with more prestigious public institutions in the state. This was a problem that went beyond research funding. Although, as a group, teaching-oriented institutions like RMU enrolled the largest share of students in the state, they were eclipsed by their elite research counterparts when it came to per-student funding allocations. "We have at least twice as many universities [like RMU] that are, you know, pretty big actually. We have 25,000 students, [and yet] it took our president years to make the legislature consider that there might be a problem with [the student funding formula]. And so in that sense it's hard to get traction."

Collaboration emerged as a form of strategic positioning to navigate the considerable challenges faced by faculty seeking to pursue technology transfer. However, the partnerships in 
question did not involve the large corporations that figured so prominently in the aspirations of RMU faculty and leadership. Instead, they consisted of other lower-status, regional institutions facing the same difficulties with funding and a lack of mature institutional infrastructure to support technology transfer. Dr. D described an initiative formed by four regional universities that came together to pool resources that would allow them to move forward, as a team, with technology transfer activities. Most recently, the institutions had jointly retained a patent lawyer (which individually they would not have been able to afford) to serve as a consultant for all transfer activities at the four universities. They had also enlisted the help of a peer institution with more experience in technology transfer to provide feedback at specific points in the patenting process. "So we don't only compete at this point. We also try to work together and basically make some things possible that wouldn't be possible otherwise."

\section{Discussion}

As the political economy of higher education funding changes, so does the identity and organizational structure of HEIs. The steep decline in state appropriations led to institutions seeking alternate sources of funding, including from tuition increases and an intensified drive to engage in revenue-generating activities. Also tied to this phenomenon are significant shifts in traditional structures of academic labor. As the role of traditional faculty as knowledge producers intensifies, new categories of academics emerge with exclusively research-oriented responsibilities which require working with a vast array of external organizations (including other HEIs, industry, and governmental agencies), through grant activity, contracted projects, and consulting (Mohrman et al., 2008). This was the case of MidU, where the highly differentiated staffing system to support the research enterprise was congruent with the EGM's dictum that these institutions will develop greater internal complexity to better support 
knowledge production and transfer, such as changes to infrastructure and the organization of academic units.

A segmented work environment is to a large extent embedded in the logic of the EGM, with faculty evaluated on aspects such as publication productivity, success in getting external funding, and establishing partnerships with external entities that will secure additional financial and/or symbolic capital for the researchers and the institution. Yet as suggested by the wide array of research and teaching non-tenure track (NTT) positions at MidU, this differentiation is also linked to a broader trend towards more contingent types of academic appointments that do not necessarily come with increased financial or administrative support. This pattern can contribute to the creation of very different work environments for academics on different employment tracks.

At the MidU Transportation Institute, faculty on the research scientist and research professor tracks were subject a much higher degree of labor and remuneration uncertainty than their T/TT counterparts. The practice of tying a considerable portion of the research scientists' salaries to their ability to secure grants and contracts mirrors a trend observed in medical schools and public health departments at leading research universities, where faculty are expected to raise a substantial portion of their regular salaries by capturing NIH grants or grants from the pharmaceutical companies. Under this system, a faculty member's title at an institution acts largely as a placeholder that does not entail the full salary and security of more traditional appointments (Rhoades \& Torres-Olave, 2015). In this regard, scholars have raised concerns about the impact that the degree to which HEIs depend on external funding may have on academic freedom and the pursuit of basic research. Successful faculty on EGM campuses "have more money for research, more contacts with colleagues around the world, and more 
exciting intellectual challenges to pursue" (Mohrman et al. 2008, p. 10). However, for the NTT faculty at the MidU Transportation Institute, the direction of the research was closely tied to the priorities of funding agencies and corporate clients, as suggested by Dr. H's comment that faculty had the freedom to follow a line of research if they could get funding for it. There is the potential of market pressures limiting "the degrees of freedom of professors to follow creative instincts or even the logic of their own findings (idem, p. 10). With their salaries on the line, NTT research faculty had a built-in incentive to "follow the market" in their research and collaboration activities.

In this regard, an important development at MidU was the institutional push for researchexclusive units like the Transportation Institute to align with the expectations of more traditional academic departments. To be sure, the Transportation Institute epitomized the Mode 2 knowledge creation model of team-oriented, cross-disciplinary, applied inquiry (Nowotny, Scott, \& Gibbons, 2003); it also excelled at the institutional perquisite to generate research funding for the institution - in fact, the Institute was virtually self-sustaining. Yet these markers of success raised concerns that the Institute was moving close to becoming "a contract shop" divorced from the broader mission of the university. The Institute was thus under pressure to align its activities and promotion standards with those of more traditional academic units or centers like the Energy Institute — which, significantly, were also associated with higher prestige and a drastically different funding structure. However, as the university was not willing to provide additional resources to support this alignment, the research faculty faced the undue burden of "doing it all" without a commensurate support and reward structure, thus further reinforcing the segmented nature of academic appointments at MidU. This example illustrates how the pressure to conform 
to the kind of endeavors perceived to maximize institutional prestige can run counter even to structures that emerge from the EGM logic of intensifying research and collaboration activities.

In this sense, this study supports evidence that higher education institutions of different sizes, locations, and functions feel the weight of isomorphic pressures to adapt to the norms, values, and beliefs of the most prestigious competitors not because the practices are necessarily efficient or in keeping with their historical mission, but because doing so is expected to earn organizational legitimacy and thus increase the probability of organizational survival (Scott, 2008). For striving institutions lacking the financial and symbolic resources of the field leaders, however, the effort to emulate the latter's strategies can be a Sisyphean task. The case of RMU recalls the assertion that, with few exceptions, most striving universities "are destined to fall short of their goal to leverage academic prestige through entrepreneurial initiatives" (Rhoades, 2007, p. 125). One of the most visible changes in organizational dynamics resulting from the drive to facilitate access to external resources is the rise of interstitial units - such as offices of technology transfer - to bridge the gap between HEIs and the private sector (Bastedo \& Bowman 2011; Metcalfe, 2010). However, as the experience of faculty at RMU shows, there are substantial "growing pains" involved with the introduction of these units at non-researchintensive institutions. Considerable challenges arose from the steep learning curve faced by the novice technology transfer unit, along with its inability to cover the cost of the patenting process. Despite having invested considerable resources in creating an infrastructure to support research and university-industry partnerships, RMU's existing resources were not commensurate with the expenses associated with technology transfer.

Moreover, the institution's lack of a research reputation presented a significant barrier to attract additional investment from both the public and private sectors. At the academic unit 
level, it also hindered faculty's efforts to establish meaningful linkages to industry-even with companies with which close partnerships had existed in the past. A stark contrast from EGM institutions like MidU is evident especially in terms of social network capital. As non-fungible resources, social networks tend to be unevenly concentrated in subpopulations, market segments, government agencies, and so on. This gives significant and long-lasting advantages to those with access to information and a way to tap into key players in the social structure, while disadvantaging those in the fringes (Galaskiewicz \& Bielefeld, 1998). This calls to mind the comment made by Dr. A at RMU that many industry partners are mostly interested in partnering with "the Stanfords and MITs and places like that" rather than a striving institution like RMU.

\section{Concluding Thoughts}

A criticism leveled against open-systems conceptual frameworks like institutional theory is that they may overestimate the impact of environmental forces to the point of negating the agency of institutional actors. In this sense, it is important to acknowledge the creative solutions used by actors at these institutions to manage the competitive environment. Our interviews reveal the great capacity of faculty and researchers to adapt to circumstances and respond to considerable barriers. At a distinct disadvantage relative to more prestigious institutions in the state, the Chemistry and Physics faculty at RMU combined forces in creating a program that would allow them to pool resources and attract a greater number of students. Likewise, Dr. D's anecdote about the partnership between RMU and peer universities to share resources speaks to the great potential of collaborations that are rooted in the unique contexts and experiences of regional institutions, in contrast to setting up these institutions up for failure with the expectation that they should replicate the type and intensity of collaborations at EGM universities. 
Nonetheless, there is also an inherent danger in expecting institutions in similar circumstances to "cope" rather than addressing the structural limitations that are placed on them in a competitive funding allocation regime. It is worth asking whether there are ways to position these institutions to succeed in types of innovation that are congruent with their mission and allow them to become "best in kind" rather than engage in an arms race to emulate their EGM counterparts. Strategic positioning is essential for organizations to enable themselves to maneuver through threatening environments. Yet it is through differentiation and the establishment of niches — either pursuing different activities or similar activities in different ways to rivals - that institutions are truly able to gain a competitive advantage (Rhoades, 2007; Toma; 2012). Future research should consider the ways in which low-status institutions like RMU can and do create "distinctive niches connected to the opportunities and responsibilities embedded in those local contexts, and enhancing the range and distinctiveness of distinct brands found in higher education" (Rhoades, 2007, p. 123).

In this sense, there is a need for funding policies to recognize unique contributions and value of regional institutions, as well as the great potential embedded in incentivizing collaborative activities that can help these institutions build such niches, rather than pitting them against each other in pursuit of the type of research productivity standards associated with EGM institutions. State-level coordination that recognizes and rewards the unique contributions of regional, teaching-oriented institutions may be useful in combating the impulse of individual institutions to turn into a poor facsimile of their EGM counterparts. Such coordination should recognize the need to view institutional diversity as an asset and discourage the type of mission creep through which 'institutions seek the advantages that they perceive are at the 'next level' 
(Toma, 2012, p. 141). This inevitably requires a commitment to provide adequate levels of funding that help support these institutions' core missions of teaching and regional development.

Finally, although the literature has examined the characteristics of the non-tenure-track teaching faculty, much less is known about the rising numbers of full-time, non-tenure-track research faculty such as research scientists. Part of the difficulty is that these emerging forms of academic labor include a diverse set of academic positions that vary significantly in terms of work responsibilities, contractual obligations, and prestige status relative to their tenure-track counterparts. An additional complication is that the titles of full-time, research NTT faculty "are not uniform across all campuses and even, at times, on the same campus" (Kezar \& Sam, 2010, p. 37). In this regard, it behooves scholars to consider in greater detail the role that NTT and contingent faculty/researchers play in collaborative activities, as well as the former's status within institutional prestige hierarchies. There is emerging evidence suggesting that, at an international level, contractual and temporary staff play a considerable role in creating and sustaining cross-sectoral research collaborative activities (Torres-Olave et al., 2016). This role, however, is largely unrecognized by institutions and tenure stream peers. This situation speaks volumes of the changing nature of academic work worldwide, where contractual and temporary staff may now be invisibly becoming responsible for much of the labor usually associated with tenure-track or equivalent faculty. 


\section{References}

Austin, A.E., \& Baldwin, R.G. (1991). Faculty collaboration: Enhancing the quality of scholarship and teaching. Washington, D.C.: School of Education and Human Development, George Washington University.

Bastedo, M. N., \& Bowman, N. A. (2011). College rankings as an interorganizational dependency: Establishing the foundation for strategic and institutional accounts. Research in Higher Education, 52(1), 3-23. https://doi.org/10.1007 /s11162-010-9185-0

Bozeman, B., \& Corley, E. (2004). Scientists' collaboration strategies: implications for scientific and technical human capital. Research Policy, 33(4), 599-616. https://doi.org/10.1016/j.respol.2004.01.008

Bozeman, B., Fay, D., \& Slade, C. P. (2013). Research collaboration in universities and academic entrepreneurship: The-state-of-the-art. The Journal of Technology Transfer, 38(1), 1-67. https://doi.org/10.1007/s10961-012-9281-8

Brewer, D. J., Gates, S. M., \& Goldman, C. A. (2002). In pursuit of prestige. Piscataway, NJ: Transaction Publishers.

Bruneel, J., D’Este, P., \& Salter, A. (2010). Investigating the factors that diminish the barriers to university-industry collaboration. Research Policy, 39(7), 858-868. https://doi.org/10.1016/j.respol.2010.03.006

Cantwell, B., \& Taylor, B. J. (2013). Global status, intra-institutional stratification and organizational segmentation: A time-dynamic to bit analysis of ARWU position among US universities. Minerva, 51(2), 195-223. https://doi.org/10.1007/s11024-013-9228-8 
Cheslock, J. J, \& Gianneschi, M. (2008). Replacing state appropriations with alternative revenue sources: The case of voluntary support. Journal of Higher Education, 79(2), 208-229. https://doi.org/10.1080/00221546.2008.11772092

Connolly, M., \& James, C. (2006). Collaboration for school improvement: A resource dependency and institutional framework of analysis. Educational Management Administration \& Leadership, 34(1), 69-87. https://doi.org/10.1177/ 17411432060 59540

Corzo, J. (2015, April). How academic institutions partner with private industry. $R \& D$ Magazine. Retrieved from http://www.rdmag.com/article/2015/04/how-academic- institutionspartner-private-industry

D'Este, P., \& Iammarino, S. (2010). The spatial profile of university-business research partnerships. Papers in Regional Science, 89(2), 335-350. https://doi.org/10.1111/j.14355957.2010.00292.x

Eddy, P. L. (2010). Partnerships and collaboration in higher education. San Francisco, CA: John Wiley \& Sons.

Ehrenberg, R. (2003). Reaching for the brass ring: The U.S. news and world report rankings and competition. The Review of Higher Education, 26(2), 145-162.

https://doi.org/10.1353/rhe.2002.0032

Galaskiewicz, J. and, W. Bielefeld. (1998). Nonprofit organizations in an age of uncertainty: A study of organizational change. New York: de Gruyter.

Galletta, A. (2013). Mastering the semi-structured interview and beyond: From research design to analysis and publication. New York, NY: New York University Press. 
Gardner, S. K. (2013). Paradigmatic differences, power, and status: A qualitative investigation of faculty in one interdisciplinary research collaboration on sustainability science. Sustainability Science, 8(2), 241-252. https://doi. org/10.1007/s11625-012-0182-4

Goel, R., Goktepe-Hulten, D., \& Grimpe, C. (2017). Who instigates university-industry collaborations? University scientists versus firm employees. Small Business Economics, 48(3), 503. https://doi.org/10.1007/s11187-016-9795-9

Hoffman, D. \& Valimaa, J. (Eds.). (2016). Re-becoming universities? Higher education institutions in networked knowledge societies. Dordrecht, The Netherlands: Springer.

Hoffman, D. M., \& Horta, H. (2016). The CINHEKS research design: Taking stock and moving forward. In D. Hoffman \& J. Valimaa (Eds.), Re-becoming universities? Higher education institutions in networked knowledge societies (pp. 41-74). Dordrecht, The Netherlands: Springer.

Hoyla, T., Bartneck, C., \& Tiihonen, T. (2016). The consequences of competition: Simulating the effects of research strategies. Scientometrics, 108(1), 263-288. https://doi.org/10.1007/s11192-016-1940-3

Huisman, J. (2008). World-Class Universities. Higher Education Policy, 21(1), 1-4. https://doi.org/10.1057/palgrave.hep.8300180

Katz, J. S., \& Martin, B. R. (1997). What is research collaboration? Research Policy, 26(1), 118. https://doi.org/10.1016/S0048-7333(96)00917-1

Keohane, N. O. (1985). Collaboration and leadership: Are they in conflict? College Board Review, 135, 4-6. https://doi.org/10.1215/9780822387770-002 
Kezar, A. (2005). Redesigning for collaboration within higher education institutions: An exploration into the developmental process. Research in Higher Education, 46(7), 831860. https://doi.org/10.1007/s11162-004-6227-5.

Kezar, A., \& Sam, C. (2010). Special issue: Understanding the new majority of non-tenure-track faculty in higher education-demographics, experiences, and plans of action. ASHE Higher Education Report, 36(4), 1-133.

Klein, J. T. (2005). Interdisciplinary teamwork: The dynamics of collaboration and integration. In S.J. Derry, C. Schunn, \& M. Gernsbacher (Eds.), Interdisciplinary collaboration: An emerging cognitive science (pp xiii-xx). Lawrence Erlbaum Associates, Mahwah.

Laudel, G. (2002). What do we measure by co-authorships? Research Evaluation, 11(1), 3-15. https://doi.org/10.3152/147154402781776961

Lee, S., \& Bozeman, B. (2005). The impact of research collaboration on scientific productivity. Social Studies of Science, 35(5), 673-702. https://doi.org/10.1177/0306312705052359

Metcalfe, A. S. (2010). Examining the trilateral networks of the triple helix: Intermediating organizations and academy-industry-government relations. Critical Sociology, 36(4), 503-519. https://doi.org/10.1177/0896920510365920

Mohrman, K., Ma, W., \& Baker, D. (2008). The research university in transition: The emerging global model. Higher Education Policy, 21(1), 5-27. https://doi.org/10.1057/palgrave.hep.8300175

Morgan, J., \& Mulligan, C. (2014, October). When a university partners with local governments in innovative ways: Economic development can be the result. Public Management. 
Retrieved from https://icma.org/articles/pm-magazine/when-university-partners-localgovernments-innovative-ways

National Center for Education Statistics. (2018). Integrated Postsecondary Education Data System (IPEDS) Finance component. Retrieved from https://nces.ed.gov/ipeds/datacenter/InstitutionList.aspx on March 10, 2019.

Nowotny, H., Scott, P., \& Gibbons, M. (2003). Mode 2 revisited: The new production of knowledge. Minerva, 41(3), 179-194.

O’Meara, K. (2007). Striving for what? Exploring the pursuit of prestige. In J.C. Smart (Ed.), Higher education: Handbook of theory and research, vol. 22, (pp. 121-179). Dordrecht, The Netherlands: Springer.

O'Shea, R. P., Allen, T. J., Chevalier, A., \& Roche, F. (2005). Entrepreneurial orientation, technology transfer and spinoff performance of US universities. Research Policy, 34(7), 994-1009. https://doi.org/10.1016/j.respol.2005.05.011

Palinkas, L.A., Horwitz, S.M., Green, C.A., Wisdom, J. P., Duan, N., Hoagwood, K. (2015). Administration and Policy in Mental Health and Mental Health Services Research, 42(5), 533-544.

Perkmann, M., \& Salter, A. (2012). How to create productive partnerships with universities. MIT Sloan Management Review, 53(4), 79-88.

Pucciarelli, F. \& Kaplan, A. (2016). Competition and strategy in higher education: Managing complexity and uncertainty. Business Horizons, 59(3), 311-320. https://doi.org/10.1016/j.bushor.2016.01.003 
Rhoades, G. (2007). Making distinctive choices in intersecting markets: seeking niches. In R. L. Geiger, C. L. Colbeck, R. L. Williams, and C. K. Anderson (Eds.), The future of the American public research university, Rotterdam, The Netherlands: Sense Publishers.

Rhoades, G. \& Torres-Olave, B. (2015). Academic capitalism and academic labor markets: Negotiating a new academy and research agenda. In M. Paulsen (Ed.), Higher Education: A handbook of theory and research (Vol. 30) (pp. 383-430). New York, NY: Springer.

Savanur, K., \& Srikanth, R. (2010). Modified collaborative coefficient: A new measure for quantifying the degree of research collaboration. Scientometrics, 84(2), 365-371. http://dx.doi.org/10.1007/s11192-009-0100-4

Scott, W. R. (2008). Institutions and organizations. (3rd Ed.). Thousand Oaks, CA: Sage.

Sine, W. D., Shane, S., \& Gregorio, D. D. (2003). The halo effect and technology licensing: The influence of institutional prestige on the licensing of university inventions. Management Science, 49(4), 478-496. https://doi.org/10.1287/mnsc. 49.4.478.14416

Slaughter, S. and Cantwell, B. (2012). Transatlantic moves to the market: The United States and the European Union. Higher Education, 63(5), 583-606. https://doi.org/10.1007/s10734011-9460-9

Slaughter, S. \& Rhoades, G. (2004). Academic capitalism and the new economy: Markets, state and higher education. Baltimore, MD: The Johns Hopkins University Press.

Sonnenwald, D. H. (2007). Scientific collaboration. Annual Review of Information Science and Technology, 41, 643-681. https://doi.org/10.1002/aris.2007.1440410121

Tesch, R. (1990). Qualitative research: Analysis types and software tools. New York, NY: Falmer. 
Thune, T., \& Gulbrandsen, M. (2014). Dynamics of collaboration in university-industry partnerships: Do initial conditions explain development patterns? Journal of Technology Transfer, 39(6), 977-993. https://doi.org/10.1007/s10961-014-9331-5

Toma, J. D. (2012). Institutional strategy. In M. N. Bastedo (Ed.), The organization of higher education: Managing colleges for a new era (pp. 118-159). Baltimore, MD: The John Hopkins University Press.

Van Rijnsoever, F. J., \& Hessels, L. K. (2011). Factors associated with disciplinary and interdisciplinary research collaboration. Research Policy, 40(3), 463-472. https://doi.org/10.1016/j.respol.2010.11.001

Wright, M., Clarysse, B., Lockett, A., \& Knockaert, M. (2008). Mid-range universities’ linkages with industry: Knowledge types and the role of intermediaries. Research Policy, 37(8), 1205-1223. https://doi.org/10.1016/j.respol.2008.04.021

Yin, R. (2014). Case study research design and methods (5th ed.). Thousand Oaks, CA: Sage.

Zhe Jin, G. \& Whalley, A. (2007). The power of attention: Do rankings affect the financial resources of public colleges? NBER Working Paper No. 12941. Retrieved online on July 16, 2009, from http://www.nber.org/papers/w12941 


\section{Tables}

Table 1: RMU and MidU core revenues per FTE enrollment (in thousands), by source of revenue, FY2017

\begin{tabular}{lcccc} 
& \multicolumn{2}{c}{ RMU } & \multicolumn{2}{c}{ MidU } \\
& FTE & \% Total & FTE & \% Total \\
\cline { 2 - 5 } Tuition and fees & $\$ 10,425$ & 49 & $\$ 23,581$ & 24 \\
State appropriations & $\$ 4,054$ & 19 & $\$ 6,739$ & 7 \\
Government grants and contracts & $\$ 1,659$ & 8 & $\$ 21,107$ & 22 \\
Private gifts, grants, and contracts & $\$ 509$ & 2 & $\$ 8,476$ & 9 \\
Investment return & $\$ 1,913$ & 9 & $\$ 30,482$ & 31 \\
Other core revenues & $\$ 2,902$ & 14 & $\$ 7,202$ & 7
\end{tabular}

Source: National Center for Education Statistics, Integrated Postsecondary Education Data System (NCES, 2018). 


\section{Figures}

Figure 1: RMU and MidU total operating revenues, FY 2007 and 2017

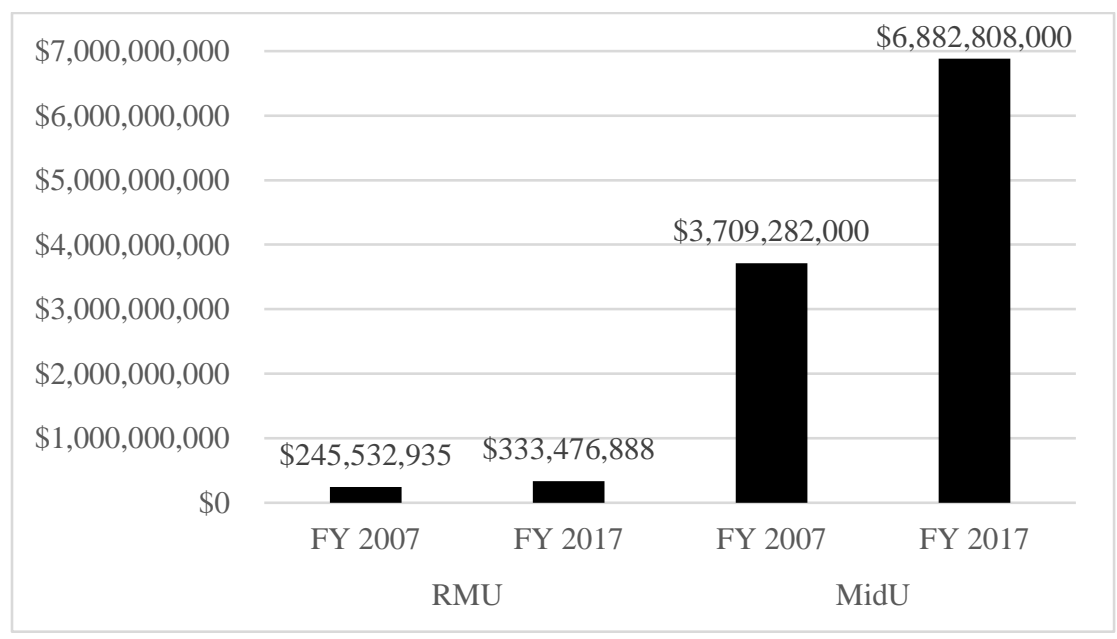

Source: National Center for Education Statistics, Integrated Postsecondary Education Data System (NCES, 2018).

Figure 2: RMU and MidU operating grants and contracts, FY2007 and 2017, by funding type

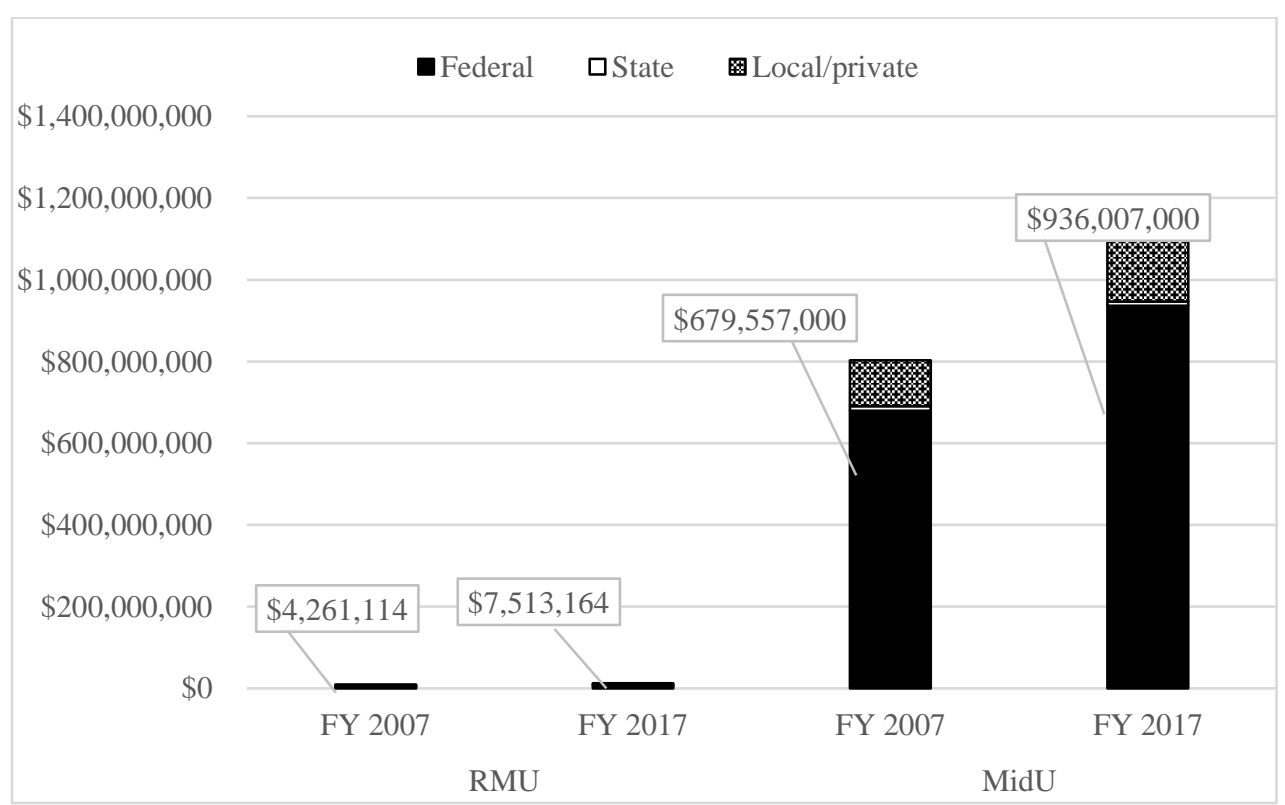

Source: National Center for Education Statistics, Integrated Postsecondary Education Data System (NCES, 2018). 
Figure 3: RMU and MidU total endowment assets, FY2007 and FY2017

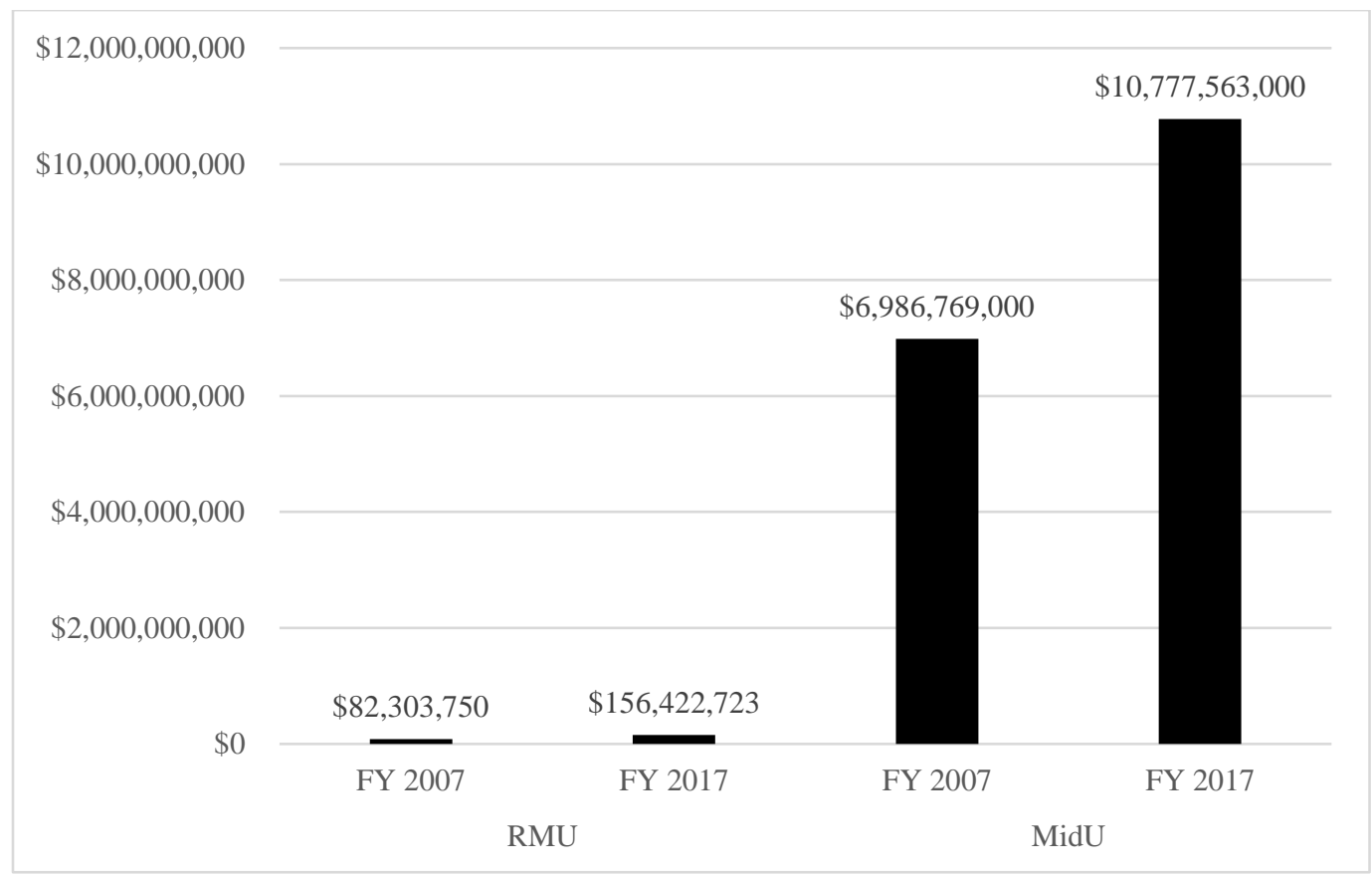

Source: National Center for Education Statistics, Integrated Postsecondary Education Data System (NCES, 2018). 